Stanislaw Klek, Alastair Forbes,

Simon Gabe, Mette Holst, Geert

ESPEN
Guidelines

Wanten, Wivind Irtun, Steven Olde

Damink, Marina Panisic-Sekeljic,

Rosa Burgos Pelaez, Loris Pironi,

Annika Reintam Blaser, Henrik Hujgaard

Rasmussen, Stephane M. Schneider, Ronan

Thibault, Ruben G.J. Visschers, Jonathan Shaffer

ВЕДЕННЯ ГОСТРОї КИШКОВОї

НЕДОСТАТНОСТІ: РЕКОМЕНДАЦІЇ

СПЕЦІАЛЬНОЇ ГРУПИ ЄВРОПЕЙСЬКОЇ

СПІЛКИ ПАРЕНТЕРАЛЬНОГО ТА

ЕНТЕРАЛЬНОГО ХАРЧУВАННЯ

\title{
MANAGEMENT OF ACUTE INTESTINAL
}

FAILURE: A POSITION PAPER FROM THE

EUROPEAN SOCIETY FOR CLINICAL

NUTRITION AND METABOLISM (ESPEN)

SPECIAL INTEREST GROUP

Дане керівництво перекладено ГО «M-Gate» під редакцією ГО «Асоціації анестезіологів України». Всі права належать Elsevier Ltd and European Society for Clinical Nutrition and Metabolism.

Список скорочень:

ВАIT - відділення анестезіології та інтенсивної терапії

ГКН - гостра кишкова недостатність

IMT - індекс маси тіла

КН - кишкова недостатність

КШФ - кишково-шкірні фістули
ПНЖК - поліненасичені жирні кислоти ПХ - парентеральне харчування

СТГ - середньоланцюгові тригліцериди ХКН - хронічна кишкова недостатність ХПАПХ - хвороба печінки, асоційована 3 парентеральним харчуванням ШКТ - шлунково-кишковий тракт

Stanislaw Klek, Alastair Forbes, Simon Gabe, 2017 
BIA - аналіз біоелектричного імпедансу ESPEN - Європейська спілка парентерального та ентерального харчування (European Society for Clinical Nutrition and Metabolism)

SIG - Спеціальна група (Special Interest Group)

\section{1. ВСТУП}

Термін «кишкова недостатність» визначає зниження функції кишечнику нижче від мінімально необхідної для всмоктування макронутрієнтів i/або води та електролітів, що обумовлює необхідність у додатковій внутрішньовенній підтримці для забезпечення здоров'я та/або росту організму [1]. Зниження всмоктувальної функції кишечнику, яка не вимагає додатково внутрішньовенного введення поживних речовин для підтримки здоров'я та/або росту організму, можна визначити як «кишкову неспроможність», або «дисфункцію» [2].

Кишкова недостатність може бути вродженою або набутою, гастроінтестинальною або системною, доброякісного або злоякісного походження [2-4].

Кишкова недостатність може розвиватися раптово або бути повільним, прогресуючим наслідком хронічної хвороби, також це може бути швидкоминучий стан зі спонтанним видужанням або тривалий процес - хронічна кишкова недостатність (ХКН).

Ірунтуючись на швидкості початку хвороби, метаболічних змінах і прогнозах, кишкову недостатність класифікують $[1,3]$ :

I тип - гострий стан, швидкоминучий, iз самостійним спонтанним одужанням;

II тип - пролонгований гострий стан, часто у метаболічно нестабільних пацієнтів, які потребують комплексного мультидисциплінарного лікування та внутрішньовенної підтримки терміном від декількох тижнів до місяців;

тип III - хронічний стан (XКН) у метаболічно стабільних пацієнтів, який вимагає внутрішньовенної підтримки терміном від декількох місяців до років. Може бути оборотним і необоротним.

Типи I та II $є$ формами гострої кишкової недостатності (ГКН). ГКН I типу - це короткочасний стан, зазвичай зі спонтанним одужанням, який діагностується приблизно в 15\% пацієнтів у періопераційний період після абдомінальних операцій або асо- ційований із тяжкими захворюваннями (травми голови, пневмонія, панкреатит), операціями на серці [1]. Поопераційна кишкова непрохідність зазвичай спонтанно минає протягом декількох днів і вимагає мінімального втручання [1]. Такі пацієнти зазвичай перебувають у хірургічних відділеннях, але деякі пацієнти відділень інтенсивної терапії також підпадають під цю категорію [1].

Термін «синдром гострого пошкодження ШКТ» був запропонований, аби віднести гастроінтестинальну дисфункцію до синдрому поліорганної дисфункції у критичних пацієнтів, незалежно від наявності або відсутності первинної абдомінальної патології [6]. Гостре пошкодження ШКТ І ступеня (самостійно минає) та II ступені (вимагає втручань) приблизно відповідають ГКН I типу 3 аналогічною тактикою ведення та потребами [6].

Тип II $є$ досить непересічним клінічним станом, який супроводжується септичними, метаболічними та комплексними нутритивними ускладненнями. Як правило, цей стан розвивається внаслідок травми; також можливий розвиток ГКН внаслідок гострих станів (заворот кишок, защемлена грижа, мезентеріальний тромбоз або абдомінальна травма), які вимагають видалення великих ділянок кишечнику. Можливо виникнення цього синдрому разом з ускладненнями операцій на кишечнику (неспроможність анастомозу, невиявлене пошкодження кишки, фістула, діастаз м'язів передньої черевної стінки, лапаростомія/«відкритий живіт»), часто на тлі існуючих супутніх захворювань [3]. Британське дослідження Lan et al. показало, що ГКН II типу асоційовано 3 хірургічними ускладненнями (32\%), хворобою Крона (21\%), порушенням моторики (14\%), судинною ішемією (13\%), злоякісними новоутвореннями (8\%), променевою травмою $(2 \%)$, целіакією $(2 \%)$ тощо $(8 \%)[3]$.

Пацієнти з ГКН II типу зазвичай потребують спеціалізованої медичної допомоги 3 мультидисциплінарним лікувальним підходом, реалізувати який слід, зокрема, шляхом створення профільних відділень кишкової недостатності, а також палат інтенсивної терапії для таких пацієнтів $[1,3]$. Щорічна захворюваність на кишкову недостатність II типу становить 9 осіб на мільйон $[1,5]$. 


\section{CLINICAL PRACTICE / EXPERIENCE}

Найчастіший результат (чого?) - цілковите відновлення функції (близько 40\% випадків), тривале харчування через ентеральну трубку (включаючи харчування за допомогою ентероклізису та реінфузії хімусу), або перехід у ГКН ІІІ типу, який вимагає тривалого домашнього парентерального харчування (разом близько 50\%). Внутрішньогоспітальна смертність від КН ІІ типу сягає близько 9,6$13 \%[1,7-15]$.

3 нагоди випуску нових клінічних протоколів, присвячених низці захворювань, Європейська спілка парентерального та ентерального харчування (ESPEN) доручила Спеціальній групі (SIG) із гострої кишкової недостатності та хронічної кишкової недостатності створити документ із визначеннями та рекомендаціями 3 приводу ведення пацієнтів із цією патологією. Натомість даних щодо ГКН бракує, опубліковано лише декілька оглядів, і досі немає жодних рекомендацій. Ця група мала завдання швидше розбити рекомендації, ніж протоколи.

Основна мета даного документу - надати рекомендації щодо лікування ГКН II типу та визначити напрямки для подальших досліджень.

\section{2. МЕНЕДЖМЕНТ}

\section{1. Загальні міркування}

У типовому випадку пацієнт із ГКН типу II характеризується наявністю високої кишкової нориці або ентеростоми, з асоційованим сепсисом і проблемами, пов'язаними із синдромом короткої кишки (до $30 \%$ нових госпіталізацій із ГКН). Відсутній узгоджений клінічний підхід до ГКН, хоча 3 цією патологією лікарі стикаються з більшою або меншою частотою в усіх відділеннях абдомінальної хірургії. Певну приблизну оцінку досвіду можна зробити завдяки Європейському огляду даних щодо кишковошкірних фістул (КШФ), виконаному Спеціальною групою 3 гострої кишкової недостатності (AIF SIG) та оприлюдненому 2012 року на конгресі ESPEN у Барселоні [14]. Він показав, що учасники вважали себе досвідченими у лікуванні КШФ лише до певної міри: хірурги - на 75\%, терапевти на 68\%, медсестри - на 69\%, дієтологи - на $61 \%$ і фармацевти - на 44\% [14]. Відшкодування витрат вважається серйозною проблемою: лише 18\% респондентів вважали, що
PAIN, ANAESTHESIA \& INTENSIVE CARE IN2 2017

системи кодування враховують усі потреби цих пацієнтів, навіть якщо $27 \%$ вважають, що існує відповідна фінансова компенсація в цілому [14]. Ці дані свідчать про необхідність рекомендацій і керівних принципів, які б стосувалися діагностики та лікування ГКН.

Хоча ключовим аспектом терапії $є$ лікування основного захворювання, що призвело до ГКН, загалом визнається, що є деякі мультидисциплінарні лікувальні заходи, які необхідно реалізувати для успішного лікування ГКН. Для конкретного випадку пацієнта з ГКН, в якого є КШФ, група Maastricht запропонувала схему, підсумовану в таблиці $1[9,11]$. Дуже схоже керівництво (з абревіатурою SNAP: сепсис, харчування, анатомія, план) надійшло з блоку Salford y Великобританії [3].

Таблиця 1 - режим SOWATS для кишково-шкірної фістули або тимчасової ентеростомії

$\mathrm{S}$ - контроль сепсису

$\mathrm{O}$ - оптимізація харчового статусу

$\mathrm{W}$ - догляд за раною

А - анатомія кишечнику та фістули

$\mathrm{T}$ - час операції

$\mathrm{S}$ - планування операції

Типи КН

Табл. 2. Мультидисциплінарний підхід до лікування ГКН ІІ типу

Контроль сепсису включає виявлення його ознак, радіологічний/хірургічний дренаж рідини та абсцесів, а також індивідуалізовану антибіотикотерапію. Оптимізації харчового статусу за допомогою парентерального i/aбо ентерального харчування має передувати оптимізація кислотно-лужного балансу та водно-електролітного статусу в тому числі шляхом регідратації рідинами (внутрішньовенно, ентерально та/або перорально) та використання антисекреторних препаратів й інгібіторів моторики (зазвичай інгібітори протонної помпи та лоперамід відповідно). Також вживаються заходи запобігання рефідинг-синдрому після початку нутритивної підтримки у значно виснажених хворих. Ведення ран вимагає спеціалізованого сестринського догляду із застосуванням ранового протектора, приладдя для стоми, відсмоктування рідини, пов'язок із вакуумними системами тощо. Необхідні активна реабілітація та залучення будь-якої залишкової або виключеної частини кишечнику, зазвичай шляхом 


\section{Таблиия 1.}

\begin{tabular}{|c|c|c|c|c|c|}
\hline & & Описання & Тривалість & Приклади & Мета терапії \\
\hline I тип & ГКН I & $\begin{array}{c}\text { Гострий стан. Зазвичай } \\
\text { поеднуеться } 3 \\
\text { дисфункцією інших } \\
\text { органів. Часто самостійно } \\
\text { розрішуеться, коли } \\
\text { дисфункції інших органів } \\
\text { кореговані. }\end{array}$ & Дні & $\begin{array}{c}\text { Паралітична } \\
\text { постопераційна кишкова } \\
\text { непрохідність або як } \\
\text { частина синдрому } \\
\text { поліорганної } \\
\text { недостатності }\end{array}$ & $\begin{array}{c}\text { Виживання. Стабілізація } \\
\text { гомеостазу. Розрішення } \\
\text { КН. }\end{array}$ \\
\hline II тип & ГКН II & $\begin{array}{c}\text { Подовжений гострий стан. } \\
\text { Прогресуюча метаболічна } \\
\text { нестабільність. }\end{array}$ & $\begin{array}{l}\text { Від тижнів до } \\
\text { місяців }\end{array}$ & $\begin{array}{c}\text { Рецидивуючий } \\
\text { абдомінальний сепсис } 3 \\
\text { фістулами, або без. } \\
\text { Гостра фаза синдрому } \\
\text { короткого кишківника. }\end{array}$ & $\begin{array}{c}\text { Досягнення стабільного стану } \\
\text { без приеднання сепсису або } \\
\text { інших органних дисфункцій. } \\
\text { Розрішення КН або перехід в } \\
\text { хронічну фазу. }\end{array}$ \\
\hline III тип & XKH & $\begin{array}{c}\text { Хронічна органна } \\
\text { дисфункція без супутньої } \\
\text { дисфункції інших органів. } \\
\text { Стабільний перебіг. }\end{array}$ & $\begin{array}{l}\text { Від місяців до } \\
\text { років }\end{array}$ & $\begin{array}{l}\text { Синдром короткого } \\
\text { кишківника. } \\
\text { Порушення моторики } \\
\text { кишківника }\end{array}$ & $\begin{array}{l}\text { Підтримання гомеостазу. } \\
\text { Оптимізація харчового } \\
\text { статусу та догляду за } \\
\text { ранами. Відновлення } \\
\text { цілісності кишківника, де це } \\
\text { можливо. }\end{array}$ \\
\hline
\end{tabular}

\section{Табличя 2.}

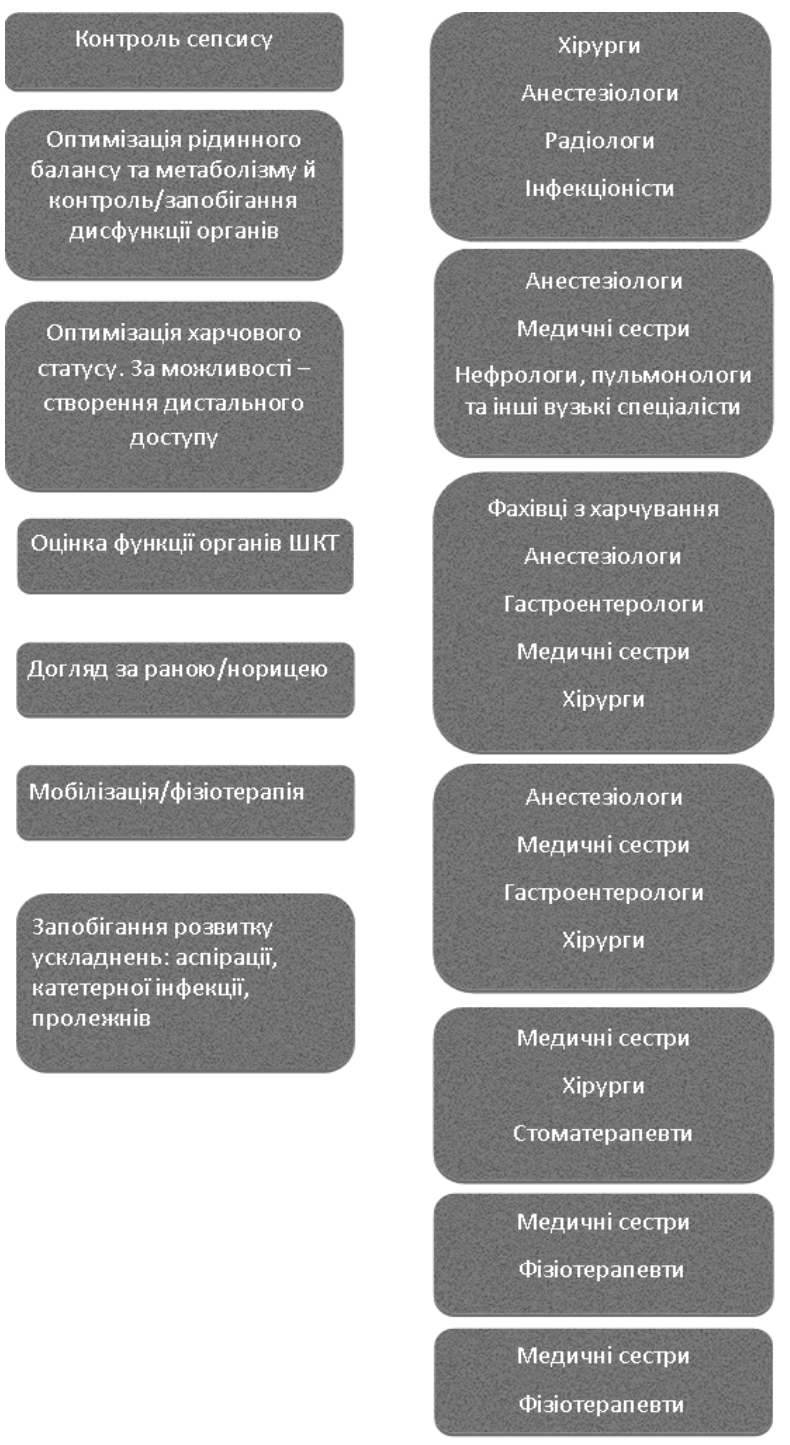

ентерального годування, іноді фістулоклізису або реінфузї проксимального вмісту. В подальшому точна оцінка стану та функції шлунковокишкового тракту за допомогою рентгенологічних методів дозволить спланувати наступне хірургічне лікування, але потрібно розуміти, що хірургічне втручання раніше 3-місячного терміну 3 моменту первинної травми зрідка є правильним рішенням. Після цього терміну втручання можливо по завершенні запальних процесів (нормалізація маси тіла та показників сироваткового альбуміну, маркерів запалення, а також, можливо, зниження секреції 3 фістули) [11, 17].

Ретельне дотримання вищевказаних пунктів $є$ запорукою успішного лікування пацієнта 3 КШФ. Аналогічний підхід SNAP також фокусується на виявленні та лікуванні сепсису [3] 3 дослідженням культур і мазків, виконанням абдомінальної візуалізації та ідентифікації інших можливих джерел інфекції (наприклад, респіраторних, інфекції сечових шляхів, ендокардиту). Необхідним є харчовий і дієтичний контроль, за необхідності 3 додатковим харчуванням із використанням оптимального шляху: ентерального (назогастральний зонд, ентеральне клізмування, реінфузія 


\section{CLINICAL PRACTICE / EXPERIENCE}

хімусу) або парентерального (периферичного або центрального).

Отже, обидва терапевтичні підходи концентруються на спільному наборі ключових елементів, які можуть бути застосованими до загального клінічного догляду за ГКН із або без кишково-шкірної фістули.

\section{3. ОСНОВНI АСПЕКТИ}

\section{ЛІКУВАННЯ ГКН}

\section{1. Контроль сепсису}

Сепсис - основна причина смерті пацієнтів із ГКН. Якщо джерело інфекції виявлено в черевній порожнині, необхідними заходами є негайне видалення та/або адекватне дренування. Проте в деяких випадках видимого джерела інфекції не знаходять, тому причиною сепсису розглядають бактеріальну транслокацію (наприклад, за коліту, вираженого здуття кишечнику, підгострої ішемії без перфорації тощо) $[18,19]$. Обов'язково слід проводити ретельний нагляд і виявляти ранні симптоми сепсису. Відповідно до результатів Visschers et al. ці симптоми можуть бути стертими через низький харчовий статус або наявність супутнього захворювання [9, $11,13]$.

Отже, пацієнти можуть не мати типових симптомів інфекції, таких як лихоманка або підвищений рівень С-реактивного протеїну в крові. Натомість клінічні симптоми неконтрольованого сепсису можуть включати в себе тахікардію, втомлюваність, енцефалопатію, затримку рідини та набряки, жовтяницю та, врешті решт, ознаки органної недостатності. Лабораторні тести можуть виявити лейкопенію або лейкоцитоз, ізольовану лімфопенію, низький рівень гемоглобіну, зниження вмісту альбуміну та трансферину в плазмі, а також патологічно змінені функціональні проби печінки.

Хоча індивідуалізована таргетна антимікробна терапія, дібрана залежно від результатів посіву, $\epsilon$ необхідною, їі ефективність як єдиного виду лікування простежується лише в поодиноких пацієнтів is ГКН. Тому вкрай важливим $\epsilon$ виявлення та лікування причин сепсису, наприклад, дренування (перкутанне або хірургічне) абсцесу черевної порожнини. Також треба враховувати позаабдомінальні джерела
PAIN, ANAESTHESIA \& INTENSIVE CARE IN2 2017

сепсису, серед яких пневмонія є найбільш типовою [20]. Центральний венозний катетер має завжди розглядатись як можливе джерело інфекції [10]. Слід пам'ятати про ризик вторинного грибкового сепсису в пацієнтів у тяжкому стані з пролонгованим сепсисом та антибіотикотерапією в анамнезі. Це надто ймовірно у пацієнтів із поганою гігієною ротової порожнини [10].

\section{2. Оптимізація водного та харчового статусу}

Клінічний і метаболічний статус пацієнта з ГКН залежить від ступеня та локалізації гастроінтестинальної дисфункції, основного захворювання та функцій інших органів. У випадку синдрому короткої кишки статус пацієнта також залежить від обсягу резекції та наявності або відсутності ілеоцекального клапана та/або товстої кишки.

Впродовж початкової фази основну терапію інфузією та харчуванням спрямовано на досягнення стабільної гемодинаміки за допомогою поповнення рідини та електролітів. У подальшому основними завданнями $є$ контроль втрат рідини та покриття енергетичних витрат.

3.2.1. Заміщення рідини та електролітів. Рідинна ресусцитація $є$ обов'язковою для всіх пацієнтів із ГКН і має бути розпочата раніше від будь-яких нутритивних втручань. Об'єм рідинного пасажу через тонку кишку сягає близько 6-8 л на день, в основному це - шлунково-кишковий секрет і випита рідина. Приблизно 80\% цієї рідини реабсорбується в порожній і клубовій кишках, і лише 1,5 л у нормі досягає товстої кишки, де все, крім 150 мл, реабсорбується. Підвищена функція товстої кишки може збільшити абсорбцію до 5 л води за 24 години [15]. У пацієнтів, які перенесли значну резекцію товстої кишки, втрати води асоційовано з залишковою довжиною тонкої кишки, і вони зростають через парціальну або тотальну резекцію товстої кишки. У пацієнтів із термінальною єюностомією або проксимальною ілеостомією часто розвиваються дегідратація та дефіцит електролітів (надто магнію, калію та натрію). Нормальні рівні електролітів мають бути досягнуті в усіх пацієнтів із ГКН, не в останню чергу тому, що електролітні порушення можуть погіршити шлунково-кишкову моторику [21]. Резекція клубової кишки викликає більші мальабсорбцію та діарею, ніж 
резекція порожньої кишки в зв'язку 3 надлишком жовчних кислот і неперетравлених жирів, що досягають товстої кишки, а також через низьку здатність порожньої кишки до адаптації. Величина кишкових втрат рідини на тлі ГКН є більшою в ранній період після резекції та може посилюватися через супутні чинники, такі як запалення або порушення перистальтики. Наявність інтраабдомінального сепсису або інших захворювань (наприклад, хвороби Крона, целіакії, радіаційного ентериту або хвороби Аддісона) може значно посилити втрати, незважаючи на наявність більшої ділянки збереженого кишечнику (тобто за відсутності синдрому короткої тонкої кишки).

Рідини мають вводитись у кількості, яка покриватиме всі втрати та забезпечуватиме діурез щонайменше 1 мл/кг/год. (або 25 мл/кг/день). Пацієнти завжди мають отримувати достатню кількість рідини, зазвичай із перевищенням стандартного об'єму 30-40 мл/кг/день [14]. Значні об’єми рідини та електролітів втрачаються через пронос, через стому або назогастральний дренаж, і мають бути контрольованими та вчасно відновленими. Вимірювання концентрації натрію в сечі є досить чутливим показником стану гідратації, показник натрію сечі $<20$ ммоль/л (або $<50$ ммоль / 24 год.), разом із відношенням $\mathrm{Na} / \mathrm{K}<1$ вказують на рідинний та/або натрієвий дефіцит. Ці зміни будуть передувати будь-яким змінам вмісту креатиніну або сечовини в крові. Ці показники слід контролювати декілька разів на тиждень, доки не буде досягнуто стабільного водного балансу.

Європейське опитування (European survey) показало, що достатня гідратація була складною проблемою. Зокрема, лише $75 \%$ і $51 \%$ центрів мали настанови щодо того, чи взагалі пити, чи їсти пацієнтам із гострою або хронічною КШФ відповідно [11].

Інфузійна терапія у септичних хворих $€$ найскладнішим завданням, важко уникнути позитивного водного балансу на цій стадії. Оптимізація водного балансу є необхідною для забезпечення адекватної перфузії органів та уникнення подальшого ураження органів. Водночас швидкий і належний контроль джерела сепсису необхідний для обмеження тривалості нестабільної фази та можливості ранньої «де-рисусцитації» (пізня мата - орієнтована дегідратація) для досягнення негативного водного балансу без загрози для системи зсідання крові [22].

3.2.2. Нутритивна підтримка. Введення поживних речовин $\epsilon$ ключовим аспектом в усіх пацієнтів із ГКН і вимагає оцінки, планування, терапії та моніторингу.

3.2.2.1. Оиінка харчового статусу. Для оцінки харчового статусу та ризику можуть бути використаними деякі скринінгові тести. Всі вони є комплексними та зазвичай включають дані про втрату ваги, індекс маси тіла (IMT), кількість спожитої їжі та поправку на тяжкість захворювання (NRS-2002); детальнішу інформацію можна знайти в нещодавньому дослідженні ESPEN Consensus Statement [23].

Відповідно до цього є два основних варіанти діагностики мальнутриції [23]. Перший варіант вимагає певного IMT зниження показника до $<18,5$ кг/ м $^{2}$ свідчить про мальнутрицію [23]. Другий варіант вимагає наявності втрати ваги без зусиль (ненавмисної) та/або зниження IMT або індексу безжирової маси тіла (FFMI). Відсоток втрати ваги може бути або $>10 \%$ від звичайної ваги за невизначений термін, або $>5 \%$ за 3 місяці. Зниженим вважається показник IMT $<20$ кг $/ \mathrm{M}^{2}$ у молодих осіб або IMT $<22$ кг $/ \mathrm{M}^{2}$ в осіб віком понад 70 років. Низьким індексом безжирової маси тіла

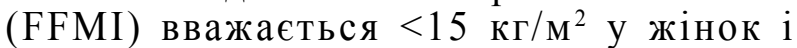
$<17$ кг/м² у чоловіків [23].

В усіх пацієнтів із ГКН має бути проведений повний початковий скринінг для оцінки харчового статусу. Антропометрія $\epsilon$ вірогідним методом. Основними антропометричними показниками $є$ маса тіла (фактична, ідеальна, скоригована), IMT, окружність кисті та товщина шкірної складки [15]. Натомість вірогідність цих антропометричних показників скомпрометовано у пацієнтів із ГКН, адже вони мають досить значні варіації гідратації, надто на ранніх стадіях, а також у пацієнтів із нестабільними кишковими втратами (надто схильні до дегідратації). 3 тими ж проблемами стикаються, використовуючи метод аналізу біоелектричного імпедансу (BIA) [24].

ВIA - метод оцінки складових людського тіла, який теоретично може бути використаний для оцінки гідратації тканини та 


\section{CLINICAL PRACTICE / EXPERIENCE}

цілісності клітинних мембран. Проте результати цього методу можуть бути вірогідно інтерпретованими лише у пацієнтів зі стабільним водним балансом [25]. ВIA включає вимірювання імпедансу виходу, опору, фазового кута та аналіз вектора біоелектричного імпедансу (BIVA).

Фазовий кут (PhA), принаймні наразі, вважається маркером здоров'я тканин, адже залежить від маси клітин, цілісності клітинних мембран та їх функції [26]. У багатьох працях у низці клінічних ситуацій, у тому числі за ВІЛ-інфекції, раку, хірургічних і хронічних захворювань печінки продемонстровано прогностичне значення показників фазового кута [26].

Проспективне багатоцентрове наглядове дослідження фазового кута (ClinicalTrials.gov Identifier: NCT01907347), що проводиться за підтримки ESPEN, наразі з'ясовує прогнос-тичного значення цього показника у пацієнтів відділення інтенсивної терапії. Інші дослідження продемонстрували, що фазовий кут може вважатись чутливим маркером у моніторингу харчового статусу після нутритивних втручань [27-29]. На сьогоднішній день роль біоелектричного імпедансу в оцінці будови тіла, фазового кута або водного статусу не підтверджено в пацієнтів із ГКН.

Для оцінки м'язової сили та функції може бути корисним визначення сили стискання (динамометрія), але, знову ж таки, доцільність її проведення у пацієнтів із ГКН ще не доведено.

Для оцінки харчового статусу в хворих із ГКН використовують деякі показники аналізу крові: протеїни плазми (альбумін, трансферин, транстиретин), креатинін, азот сечовини крові та кількість лімфоцитів [15]. Проте жоден із цих показників не відображає вірогідно харчовий статус пацієнта.

Сироватковий альбумін слід розглядати як маркер тяжкості захворювання й операційного ризику, але не слід використовувати як показник харчового статусу в гострій фазі. У подальшому, як за буд-якої запальної реакції, альбумін переміститься 3 судинного русла в інтерстицій, що знизить рівень сироваткового альбуміну. Зниження цього показника не має прямої кореляції 3 харчовим статусом пацієнта.
PAIN, ANAESTHESIA \& INTENSIVE CARE IN2 2017

3.2.2.2. Визначення харчових потреб $i$ шляху годування. Після оцінки стану пацієнта мають бути визначеними харчові потреби. Найточнішим для оцінювання енергетичних потреб є метод непрямої калориметрії $[15,30]$. Його використання дає можливість визначити метаболічні зсуви та внести зміни до харчового плану, що забезпечує ліпший прогноз для пацієнтів відділень анестезіології та інтенсивної терапії (BAIT) [29]. Якщо метод недоступний, пацієнт має отримувати 25-35 ккал/кг/ день залежно від метаболічного стану або фази захворювання [31-33]. Використання інших прогностичних формул, як правило, дає менш точні результати [31]. У хворих із ГКН споживання білка має складати до 1,5 мг/кг маси тіла на добу, або бути еквівалентним кількості амінокислот для пацієнтів на ПХ. Усі мікронутрієнти (вітаміни, мікроелементи) та електроліти мають вводитися 3 початку нутритивної терапії. Рекомендовано вжити запобіжних заходів, якщо пацієнт має ризик «синдрому відновлення харчування» (refeeding syndrome) [15].

Планування харчування за наявності сепсису є надто складним, адже нутритивна підтримка на тлі високого катаболізму має не лише мінімізувати негативні показники енергії, протеїнів і втрати м'язової тканини за допомогою запобігання голодуванню, а й підтримувати функції тканин організму, надто печінки, імунної системи, скелетних і дихальних м'язів [15]. Хоча непряма калориметрія є методом вибору для оцінки потреб в енергії, для розрахунку потреб харчування також можна застосовувати звичайні формули. Можна стверджувати, що загальні потреби в енергії септичного хворого зрідка перевищують 25-35 ккал/кг ідеальної маси тіла на день, а споживання білка зазвичай має бути збільшено до 1,5 г/кг/добу. Надмірне споживання енергетичного субстрату, тобто перегодовування, або переїдання, $є$ шкідливим, i його слід уникати, адже це може призвести до порушення функції печінки та виникнення холестатичної жовтяниці, порушення свідомості та гіперметаболізму, що супроводжується збільшенням потреби в $\mathrm{O}_{2} \mathrm{i}$ виробленням більшої кількості $\mathrm{CO}_{2}$, що у свою чергу призводить до підвищення легеневої вентиляції [15]. 
Достатне пероральне харчування неможливо для більшості пацієнтів із ГКН. Отже, слід визначати оптимальні додаткові методи харчування. Поживні речовини можуть надходити як ентерально (через назогастральний або назоентеральний зонд, або іноді через гастростому чи єюностому, або через ентеро/фістулоклізис у дистальну частину тонкої кишки), так і парентерально (периферично або, частіше, центрально). Хоча ентеральне харчування є ліпшим способом годування, слід мати на увазі, що часто буває важко охопити всі енергетичні та білкові потреби пацієнтів 3 абдомінальним сепсисом виключно через ентеральне харчування. Негативний енергетичний баланс пов'язаний зі збільшенням числа ускладнень [15]. Тому необхідно розглянути ПХ як додатковий або основний спосіб харчування. Проте навіть найточніше розраховане харчування буде неефективним на тлі неконтрольованого сепсису, адже не забезпечуватиме збільшення м'язової маси. Крім того, відсутність поліпшення та дефіцит набирання ваги на тлі нутритивної підтримки може вказувати на розвиток сепсису.

3.2.2.3. Парентеральне харчування. Попри те, що ентеральне харчування $є$ вірогідно переважним майже в усіх групах пацієнтів, у хворих із ГКН/КШФ перевага виключно ентерального харчування $\epsilon$ сумнівною у зв'язку з порушенням функції ШКТ. Тому ПХ часто є методом вибору, окремо або в поєднанні з ентеральним харчуванням (додаткове ПХ). Внутрішньовенні жирові емульсії $\epsilon$ важливим компонентом схеми ПХ, адже вони основне джерело енергії та незамінних жирних кислот (НЖК) [15]. Соєва ліпідна емульсія була першим комерційно доступним внутрішньовенним препаратом із високим вмістом незамінних i довголанцюгових поліненасичених жирних кислот (ПНЖК). Цей препарат виявився безпечним і добре переносився в широкому діапазоні клінічних станів. Проте високий вміст омега-6 ПНЖК, які справляють прозапальний ефект, спонукав до винаходу жирових емульсій із заміною соєвої олії на інші ліпіди, такі як середньоланцюгові тригліцериди (СТГ), оливкова олія та риб'ячий жир [32]. Збагачені СТГ та оливковою олією емульсії меншою мірою схильні до перекисного окислення, ніж ПНЖК, а риб'ячий жир містить ейкозапентаєнову та докозагексаєнову кислоти, омега-3 ПНЖК, які справляють сприятливий імуномодулюючий ефект і можуть навіть проявляти протизапальні властивості. Додавання омега-3 ПНЖК риб'ячого жиру наразі рекомендовано ESPEN для ПХ хірургічних і реанімаційних хворих [33].

3.2.2.4. Ентеральне харчування. Хоча методом вибору $є$ ПХ, завжди слід враховувати й ентеральний шлях. Цей вид харчування неможливий за обструкції ШКТ, перфорації або неефективності зовнішнього дренажу та протипоказаний за порушення перфузії ШКТ у фазі гемодинамічної нестабільності.

Специфічні формули для окремих хвороб, ймовірно, не потрібні; для пацієнтів із КН можуть бути корисними стандартне харчування або ентеральні суміші, дібрані 3 урахуванням енергетичної цінності та зручності застосування. Використання спеціальних імунонутрієнтів, таких як глутамін або омега-3 ПНЖК, вимагає подальшого дослідження. Використання простих (мономерних) харчових сумішей не рекомендується як захід першої лінії, адже багато пацієнтів із ГКН мають синдром короткої кишки та є «секреторами», але ці суміші можуть бути корисними у випадках шлунково-кишкової нестерпності полімерів.

Ентеральне харчування справляє трофічний вплив на кишечник і запобігає атрофії слизової оболонки. Воно також відіграє важливу роль у підтриманні імунної системи та, не в останню чергу, в запобіганні бактеріальній транслокації.

3.2.2.5. Дистальне харчування. Крім загальних позитивних ефектів ентерального харчування, для дистального введення поживних речовин продемонстровано негативний зв'язок із біліо-панкреатичною секрецією, тобто воно здійснює так зване «клубове гальмування» $[9,34]$. Для стимуляції дистальних відділів кишечника у паці$\epsilon н т і в$, в яких цей відділ недоступний або відключений, слід розглядати можливість застосування спеціалізованих технік, таких як фістулоклізис і реінфузія хімусу $[9,11]$. Ці методи дозволяють вводити масу, утворену в проксимальних відділах, та/або харчову суміш у кишечник дистальніше проксимальної стоми або (ЕКФ). Це фізіологічний метод підготовки нижніх відділів тонкої та товстої 


\section{CLINICAL PRACTICE / EXPERIENCE}

кишки до відновлення цілісності травного тракту, він допомагає уникнути поопераційних проблем (проносу, нетримання калу, стенозу кишечника тощо).

Метод реінфузії полягає у збиранні вмісту кишечника та реінфузії в дистальну частину. Крім скорочення термінів парентеральної підтримки (іноді - їі уникнення), продемонстровано нормалізацію показників лужної фосфатази, г-глутамілтранспептидази та білірубіну у хворих із ПХ та ЕКФ-асоційованими захворюваннями печінки [34-40]. Реінфузія хімусу поліпшує кишкову функцію та харчовий статус $[39,40]$.

Інший метод - фістулоклізис - це метод, коли харчові суміші вводяться в функціонуючий кишечник дистальніше проксимальної стоми або фістули. Наприклад, фістулоклізис був успішно застосований в 11 з 12 пацієнтів, які готувались до відновної хірургії [36].

3.2.2.6. Оральне годування. За виключенням ситуацій, коли голодування рекомендовано $з$ метою допомогти загоєнню або контролю фістули (наприклад, гостра фаза, проксимальне розташування, дуже висока, багатопродукуюча нориця), пацієнтам рекомендується необмежене харчування. Рекомендовано регулярне харчування та використання пероральних харчових добавок [15]. Спостереження досвідченого дієтолога має важливе значення для досягнення найліпших результатів, не в останню чергу через проблеми 3 підвищеною секрецією у багатьох із цих пацієнтів i, як наслідок, необхідності обмеження безсольових рідин.

3.2.2.7. Моніторинг харчування. Контроль і максимально точна фіксація спожитих нутрієнтів $є$ важливими для забезпечення можливості вчасного внесення належних змін у харчову та інфузійну підтримку. У пацієнтів BAIT часті дослідження та процедури можуть викликати перебої в годуванні (надто за умов ентерального харчування), що призводить до клінічно значущої розбіжності між призначеним і реальним об'ємом поживних речовин [41-44]. Є свідчення, що корисним може бути використання аналогових візуальних шкал, але це не підтверджено для таких випадків [44].

3.2.3. Препарати для зниження втрат шлунково-киикового тракту та/або збільшення кишкової абсорбції. Для
PAIN, ANAESTHESIA \& INTENSIVE CARE IN2 2017

зниження секреції стоми або фістули можна використовувати певні препарати. Гіпергастринемія є нормальною реакцією на резекцію тонкої кишки, що призводить до підвищеної секреції соляної кислоти шлунком. Застосування інгібіторів протонної помпи (спочатку внутрішньовенно, а потім перорально або ентерально) значно зменшує гіпергастринемію та знижує дистальну секрецію [15, 46-50].

Для лікування діареї та поліпшення засвоєння поживних речовин використовується терапія, яка пригнічує перистальтику, - лоперамід, кодеїну фосфат та антихолінергічні засоби. Лоперамід незначно всмоктується та не справляє церебральних ефектів, тому для зменшення кишкових втрат безпечно й ефективно можуть використовуватися високі дози. Для подовження та посилення ефекту пацієнтам може бути рекомендовано попередньо відкривати капсули та змішувати порошок iз молочними продуктами або фруктовим соком.

Кодеїну фосфат добре всмоктується та легко проникає крізь гемато-енцефалічний бар'єр, може викликати сонливість. Натомість діє довше за лоперамід і частково блокує різні групи опіатних рецепторів кишечника, через це препарати можуть бути комплементарними. Іноді використовуються антихолінергічні препарати через їх антиперистальтичний ефект, але антихолінергічні ефекти (надто сухість у роті, яку можна сплутати зі зневодненням) обмежують їх застосування. Слід уникати застосування антиперистальтичних препаратів за наявності Clostridium difficile асоційованої діареї, та призначати їх хворим у критичному стані лише за відсутності кишкової інфекції $[51,52]$.

У пацієнтів із неоперованою товстою кишкою (або без порушення цілісності кишки) слід розглядати можливість застосування холестираміну або колестиполу, адже діарея може бути спровокованою токсичною дією невсмоктаних жовчних солей [15].

Необхідно враховувати терміни виведення секвестрантів жовчних кислот, аби уникнути взаємодії з іншими препаратами, що їх приймає пацієнт. Рекомендується їх приймання за дві години перед або після вживання будь-якого препарату чи їжі. Слід уникати або відміняти приймання цієї групи препаратів у пацієнтів із масивною ре- 
ББЛЬ, ЗНЕЕОЛЕННЯ ТА ШНТЕНСИВНА ТЕРАПІЯ К2 2017

зекцією тонкої кишки, адже їх використання може посилити мальабсорбцію жирів.

Соматостатин - циклічний пептидний гормон, що складається 314 амінокислот. Він гальмує вивільнення гормону росту та різних шлунково-кишкових і панкреатичних гормонів. Це може зменшити секрецію шлункового соку (соку підшлункової залози, зокрема), сприяти поглинанню води й електролітів, підтримці водно-електролітного балансу та кислотно-лужної рівноваги, поліпшувати кровообіг у стінці кишечника, зменшувати всмоктування бактерій i токсинів, знижувати рівень токсинів в плазмі, прискорювати завершення запальних процесів, стимулювати проліферацію Т-клітин, а також підвищувати фізичну витривалість [34].

Синтетичні форми соматостатину, такі як октреотид, зазвичай застосовуються для зменшення ентерального навантаження рідиною. Суперечливі результати отримано щодо загоєння поопераційних панкреатичних або шлунково-кишкових нориць [35]. Тим не менше, недавній мета-аналіз показує, що як соматостатин, так і октреотид, збільшують ймовірність і скорочують час закриття нориці [53]. В інших оглядах літератури продемонстровано, що в той час як спонтанне закриття відбувалося приблизно в $30 \%$ пацієнтів з ентерокутанними фістулами, 90-95\% нориць спонтанно закривалися протягом перших 4-5 тижнів $[9,45]$. Крім того, відомо, що в $20-50 \%$ пацієнтів, лікованих синтетичними аналогами соматостатину, утворюються осад або жовчні камені. Тому, хоча цей гормон може зменшити секрецію нориць, що спрощує догляд за деякими 3 цих пацієнтів, доцільність його регулярного використання залишається суперечливою.

На даний момент відсутні дані про роль кишкових чинників росту у лікуванні пацієнтів із ГКН.

Щодо медикаментозної терапії в цілому вищезгадане Європейське опитування (European survey) показало, що якщо респонденти рівномірно використовують інгібітори секреції, то інші підходи істотно різняться: $82 \%$ із них використовують опіати (в основному лоперамід), 78\% - октреотид і $65 \%$ - розчини для пероральної регідратації [14].

\section{КЛІНІЧНІ РЕКОМЕНДАЦІї / ДОСВІД}

3.3. Запобігання розвитку ускладнень i реабілітація за допомогою сестринського догляду

3.3.1. Догляд за ранами. Належні догляд за раною, за стомою, збирання калових мас і виділень із рани $з$ акцентом на ретельний захист шкіри мають вирішальне значення для успішного лікування ГКН [10]. Сьогодні доступний великий спектр засобів, які можна використовувати для рутинного догляду за раною, але ключовим аспектом успішного лікування є наявність медсестерфахівців із догляду за раною та стомою.

Нориці, які знаходяться в лапаростомній рані, є найбільшою проблемою та мають лікуватися спеціальними рановими протекторами з або без відсмоктувальної системи. Відсмоктувальна система створює негативний тиск («легкий вакуум») у мішку, що забезпечує постійний відтік рідини з рани та сприяє швидшому загоєнню. Ця система також створює умови та стимулює ріст здорової сполучної тканини. Застосування спеціальної вакуумної техніки закриття рани має свої певні переваги. Проте застосування цієї техніки на незахищену (оголену) кишку в дефекті черевної стінки скоріше пошкодить кишечник, ніж допоможе в загоєнні нориці або закритті рани, тому застосування такої техніки зазвичай не рекомендується. Планове очищення рани двічі або тричі на день із фізіологічним розчином та антисептиком або кишковим вмістом має супроводжуватись лікувальним харчуванням, аби підвищити ймовірність закриття нориці.

\subsection{2. Догляд за порожниною рота.} Пацієнту, який потребує понад кількагодинного голодування або режиму «Nil By Mouth», необхідні конкретні вказівки та медсестринський догляд, аби знизити дискомфорт і заохотити продовжувати дотримувати режиму. Режим «Nil By Mouth» часто спричинює дискомфорт, а саме: ксеростомії (відчуття сухості язика та ротової порожнини), труднощі в розмові, густу та в'язку слину, відчуття брудних зубів, сухості та тріщин на губах. Доведено, що суворий підхід до гігієни порожнини рота знижує ризик аспіраційної пневмонії в такій групі пацієнтів. Ці дані обов'язково слід враховувати в догляді за пацієнтами з ГКН.

3.3.3. Догляд за катетером. Необхідно підкреслити, що відповідати за ведення 


\section{CLINICAL PRACTICE / EXPERIENCE}

внутрішньовенних катетерів може лише персонал, який має відповідну кваліфікацію. Так само всі медсестри, які беруть участь у догляді за катетером, повинні знати протокол асептики. Методи, які зменшують ймовірність інфікування внутрішньовенного катетера, включають правильне миття рук, використання стерильних бар'єрних технік, обробку шкіри хлоргексидином, вчасне видалення катетерів, які не використовуються, та уникнення феморального розташування катетера [56]. Протимікробні покриття катетерів можуть знижувати колонізацію катетера та рівень катетеріндукованих інфекцій, але жодних переваг у зменшенні частоти клінічно діагностованого сепсису або смертності не було продемонстровано [57]. Наслідком дотримання чіткого протоколу догляду за катетером $є$ відсутність катетер-індукованого сепсису в спеціалізованих відділеннях КН [58].

Вибір катетера $є$ менш важливим, ніж догляд за ним. Периферично розташовані центральні катетери (PICC), центральний тунелізований катетер із манжеткою «сuffed line» або порти мають своїх прихильників. Загальним компромісом є використання PICC на початку, з подальшим переходом до центрального тунелізованого катетера 3 манжеткою, якщо пацієнт потребує домашнього ПХ. Усі катетери мають встановлюватися 3 дотриманням усіх умов асептики [3].

3.3.4. Мобілізація. Незважаючи на відсутність конкретних доказів ранньої реабілітації хворих із ГКН II типу, як правило, шкідливі ефекти «ліжкового режиму» вимагають ранньої активізації цих пацієнтів за участю медичного персоналу [59]. Мобілізація під наглядом фізіотерапевтів і медичних сестер за чітким протоколом для оцінки здібностей пацієнта $\epsilon$ необхідною умовою для досягнення раннього пересування пацієнтів у BAIT і відділеннях особливого догляду [60]; логічно екстраполювати ці дані на пацієнтів із ГКН.

3.3.5.Уникнення респіраторних та інших ускладнень. Пацієнти з ГКН мають високий ризик респіраторних ускладнень. Слабкість дихальних м'язів зі зниженою рухомістю грудної стінки та збільшення частоти легеневих ускладнень спостерігали
PAIN, ANAESTHESIA \& INTEINSIVE CARE IN2 2017

у виснажених пацієнтів, які перенесли планове хірургічне втручання на верхніх відділах черевної порожнини [61].

Чинники, що підвищують ризик розвитку легеневих ускладнень після екстреної хірургії черевної порожнини, включають: вік $>50$ років, IMT $<21 \mathrm{\kappa г} / \mathrm{M}^{2}$ або $>30 \mathrm{\kappa г} / \mathrm{M}^{2}$, верхню або верхньо-серединну лапаротомію [18]. Чинники ризику аспірації шлункового вмісту включають: інтубації, блювання, положення на спині, наявність шлункового зонда, старечий вік, хірургічні втручання в черевній порожнині, а також зниження моторики [62]. Очевидно, всі ці несприятливі чинники властиві пацієнтам із ГКН і пролонгованим сепсисом, які додатково мають значну втому, підвищений ризик розвитку енцефалопатії та критичну полінейроміопатію. Численні процедури та пов'язані з ними високі потреби в знеболюванні також збільшують ризик.

Вкрай важливо уникати седації в цих пацієнтів під час спонтанного дихання. Радіологічні процедури, зокрема КТ черевної порожнини, яка виконуються в положенні пацієнта лежачи на спині, 3 ентеральним контрастом, під час спонтанного дихання, у пацієнтів із ГКН також створюють додатковий ризик, тому їх виконання має бути чітко обгрунтованим і проведеним обережно. Під час щоденного догляду вирішальна роль у лікуванні пацієнтів належить медсестрам, які мають забезпечити піднімання головного кінця ліжка щоразу, коли це можливо, виконання пацієнтом дихальних вправ, контроль приймання їжі або води в суворо оптимізованому положенні (переважно сидячи).

Потрібен адекватний контроль болю для комфорту пацієнта та активізації, а також мінімізації ризику виникнення респіраторних ускладнень, викликаних гіповентиляцією з ателектазами. Епідуральна аналгезія після абдомінальних операцій має переваги в контролі болю та дозволяє уникнути опіатних аналгетиків, але зазвичай не використовується у пацієнтів із ГКН через тривалість застосування та високий ризик септичних ускладнень [63-65].

3.3.6. Психологія. Хворі з ГКН II типу часто госпіталізуються на тривалий час i мають перебувати на великій відстані від своїх рідних. Розвиток посттравматичних стресових розладів, надто за наявності 
поопераційних ускладнень - доволі поширене явище. Досвідчений штатний психолог, який допомагатиме цим пацієнтам i надаватиме кваліфіковані поради персоналу, буде дуже корисним членом мульдисциплінарної команди.

\section{4. Хірургічні підходи}

Ефективне лікування абдомінального сепсису $є$ найважливішим чинником визначення прогнозу для пацієнтів із ГКН, i будьяка затримка погіршить результат $[65,66]$. Лікування абдомінального сепсису вимагає контролю джерела інфекції шляхом лапаротомії/лапароскопії або за допомогою рентген-керованого мініінвазійного дренажу, іноді навіть за допомогою комбінації обох методів. Таргетна антибактеріальна терапія має доповнювати хірургічні методи лікування.

3 хірургічної точки зору, якщо тонку кишку була відкрито, важливо не намагатися накладати анастомози за наявності перитоніту. Замість цього два кінці кишки мають бути екстратериторизованими, якщо неможливо дренувати кишковий вміст без резекції кишки. Слід мати на увазі, що черевна порожнина може бути скомпрометованою протягом декількох тижнів або навіть місяців після лапаротомії, тому будьяка реконструктивна хірургія може бути небезпечною.

Отже, ранні оперативні втручання мають бути обмеженими для контролю сепсису. У випадку значної абдомінальної контамінації, посилення ішемії / розвитку некрозу та/або персистуючої абдомінальної гіпертензії черевна порожнина може лишатися відкритою («відкритий живіт» або лапаростомія) впродовж декількох днів.

Відповідно до рекомендацій Асоціації хірургів Великобританії та Ірландії, у пацієнтів із ГКН II типу реконструктивні операції не мають проводитись у період до видужання або до переходу в хронічну фазу кишкової недостатності. Цей час має бути використано для корекції дефіциту поживних речовин і загоєння ран [65-67].

\section{5. Хвороба печінки, асоційована 3} кишковою недостатністю

Пацієнти з ГКН мають ризик розвитку ускладнень 3 боку печінки [67-69]. Ці відхилення мають назву «хвороба печінки, асоційована 3 кишковою недостатністю (ХПАКН)», адже саме цей термін адекватно описує аберації печінки, на відміну від застарілого терміну "хвороба печінки, асоційована 3 парентеральним харчуванням» (ХПАПХ, англ. PNALD) [69-72].

Поширеність відхилень від норми показників функції печінки під час ПХ коливається від 15\% до 85\% [66-70]. Взагалі підвищення цих показників є помірним, вони часто нормалізуються після відновлення ентерального або перорального приймання їжі, навіть якщо ПХ триває, i зазвичай нормалізуються повною мірою, щойно ПХ припиняється $[68,70]$. Тяжкість ХПАКН залежить також від основного захворювання, надто від тривалого сепсису та наявності захворювань печінки в анамнезі. Це надто часто трапляється в новонароджених і дітей раннього віку. Етіологічні чинники ХПАКН можна розділити на три основні групи, причому більшість пацієнтів мають понад одну причину [69, 72]:

- пов'язані 3 ПХ (надлишок або нестача поживних речовин, тобто пере- або недогодовування, токсичність нутрієнтів);

- пов'язані з КН (СКК, оральне голодування, надмірний бактеріальний ріст, порушення ентерогепатичного циклу, приймання лікарських засобів, надто антибіотиків, тощо);

- пов'язані з системним та/або абдомінальним запаленням (наприклад, сепсис, інтраабдомінальні інфекції).

Безсумнівно, основною причиною ускладнень 3 боку печінки у пацієнтів із ГКН є сепсис. Тому ефективне ведення сепсису є ключовим моментом усіх інтервенцій. Профілактика інших видів ХПАКН включає усунення інших зазначених вище чинників ризику, наскільки це можливо. Дії зосереджуються на [69]:

- лікуванні нехарчових причин (оперативне втручання 3 приводу каменів жовчного міхура, лікування сепсису тощо);

- оптимізації ПХ (корекція надходження ліпідів і глюкози, 3 уникненням енергетичного перевантаження, використання ліпідних емульсій 2-го та 3-го поколінь тощо);

- відновлення ентерального або перорального приймання їжі, якщо їх не протипоказано; ймовірно, реінфузію 


\section{CLINICAL PRACTICE / EXPERIENCE}

хімусу пов'язано з поліпшенням завдяки реінфузії жовчних солей разом із травними секретами, що відновлює ентерогепатичний цикл жовчних солей та їх сигнальних систем, а також побічно - iз припиненням ПХ [37].

Коли цього не достатньо, слід приділити увагу фармакологічному лікуванню (потенційно - 3 введенням урсодезоксихолевої кислоти, холіну й таурину) або трансплантації печінки та тонкої кишки (ХПАКН є однією з найбільш поширених причин проведення трансплантації кишки).

Незважаючи на всі зусилля, ХПАКН залишається основним несприятливим прогностичним маркером, а у пацієнтів, які перебувають у спеціальному відділенні кишкової недостатності, збільшені показники білірубіну на час госпіталізації асоційовано 3 гіршим короткочасним і довгостроковим прогнозом [69].

\section{6. Центри кишкової недостатності}

Результат лікування ГКН залежить від забезпечення спеціалізованими, досвідченими, мультидисциплінарними командами, на базі відділень 3 адекватними діагностичними, терапевтичними та фінансовими ресурсами. Спеціалізовані центри КН існують лише в деяких країнах - ці ж відділення також керують процесом ПХ вдома.

Як один із ключових аспектів, що визначає якість центрів КН, SIG із гострої кишкової недостатності пропонує, аби центри, які спеціалізуватимуться на веденні ГКН II типу, приймали принаймні 20 пацієнтів на рік. Розширена міждисциплінарна команда, необхідна для ведення цих складних пацієнтів, обов'язково має включати таких фахівців: анестезіологів, інтенсивістів, радіологів, урологів, гінекологів, пластичних хірургів, психологів, реабілітологів і соціальних працівників. Пацієнти потребують комплексного ведення відкритих черевних ран, високих кишкових нориць і обслуговування багатопрофільною командою 3 харчування, надто протягом щонайменше трьохмісячного періоду до хірургічного відновлення цілісності кишечника. Для досягнення цієї мети необхідно створення реабілітаційних центрів, які є більш пристосованими, ніж лікарні $з$ догляду за пацієнтами з гострими станами. Лише деякі відділення мають
PAIN, ANAESTHESIA \& INTEINSIVE CARE IN2 2017

необхідні ресурси, але в усьому світі мають бути розбудовані та розвинені центри цілковитої реабілітації для поліпшення результатів лікування пацієнтів із КН.

SIG із гострої кишкової недостатності пропонує такі показники якості для центрів кишкової недостатності, які лікують хворих iз кишковою недостатністю II типу.

\section{Структура}

1. Спеціалізоване відділення або спеціальний блок у межах відділення.

2. Обов'язковий склад співробітників із досвідом ведення КН ( мультидисциплінарна команда фахівців із КН:

- кваліфіковані гастроентерологи та хірурги 3 виділеним часом, відведеним для лікування КН;

- кваліфіковані медсестри (з харчування, догляду за стомою, догляду за раною), фармацевти та дієтологи - фахівці із КН. 3. Основні ресурси:

- належна кількість медсестер для пацієнтів із КН у відділенні;

- локальні засоби інтенсивної терапії;

- інтервенційна рентгенологічна підтримка;

- наявність фахівців зі спеціальними навичками венозного доступу;

- мультидисциплінарна амбулаторія для пацієнтів із КН;

- організація цілодобового доступу до консультації суміжних фахівців.

Організація процесу лікування:

- використання протоколів оцінювання i ведення (наприклад, нутритивна оцінка, догляд за катетером, догляд за раною, водний баланс, парентеральне й ентеральне харчування);

- структуроване збирання даних для ведення пацієнта, моніторингу та контролю якості;

- регулярний аудит клінічної роботи.

Показники результатів:

- смертність;

- рефістулізації;

- зараження ЦВК;

- незаплановані повторні госпіталізації;

- незаплановані хірургічні/інвазійні втручання;

- рівень якості життя (ЯЖ).

* Інцидентність інфекцій кровобігу, пов'язаних із катетеризацією. У досвідчених центрах можна очікувати в діапазоні від 0,14 
до 1,09 епізодів на рік у пацієнтів із хронічною КН $[73,74]$.

\section{7. Напрямки подальших досліджень}

Майбутні дослідження мають враховувати епідеміологію, чинники ризику та наслідки ГКН I і II типів. Детальніше необхідно вивчити роль сигнальних систем жовчних солей у погіршенні показників функції печінки. Дослідження форма хірургічної та медичної допомоги мають бути спрямованими на надання доказовості вибору методів і термінів первинного лікування, а також на пізніших стадіях, коли можливі множинні повторні операції/ втручання. Особливу увагу слід приділяти стратегіям, які виключають утворення нориць або стимулюють загоєння. Кількість пацієнтів, як відомо, є незначною, тому рекомендуються багатоцентрові дослідження. Заплановане багатоцентрове проспективне рандомізоване контрольоване дослідження FRY, фінансоване Французькою громадською програмою клінічних досліджень, франкомовним Товариством клінічного харчування та обміну речовин (SFNEP) і ESPEN, буде оцінювати вплив реінфузії хімусу порівняно з ПХ на частоту ускладнень впродовж одного місяця після хірургічного відновлення цілісності кишечника у пацієнтів із тимчасовою високою подвійною ентеростомою. Додаткові сфери дослідження будуть включати ті хірургічні та рентгенологічні методи (в тому числі плаги й імплантати), а також медичні процедури (в тому числі застосування чинників росту), які сприятимуть адаптації кишечника та закриттю нориць.

Місце нових нутритивних і хірургічних втручань та фармакологічних інновацій у цілому вимагатиме офіційної оцінки перед їх впевненим включенням в алгоритми лікування пацієнтів із ГКН ІІ типу. Слід зазначити, що попри наявність проблем у дослідження рідкісного стану в неоднорідній популяції, де важко побудувати адекватні дизайни, починають з'являтися важливі розробки.

\section{Конфлікт інтересів}

Конфлікт інтересів відсутній.

\section{Джерела фінансування}

Засідання SIG із гострої кишкової недостатності фінансуються ESPEN. Автори отримали гонорари спікерів і покриття витрат конференції від медичної індустрії харчування; відсутні інші фінансові або інші конфлікти інтересів.

\section{СПИСОК ЛІТЕРАТУРИ}

1. Pironi L, Arends J, Baxter J, et al. ESPEN position paper. Definition and clas- sification of intestinal failure in adults. Clin Nutr 2015.

2. O'Keefe SJD, Buchman AL, Fishbein TM, Jeejeebhoy $K N$, Jeppesen PB, Shaffer J. Short bowel syndrome and intestinal failure: consensus definitions and overview. Clin Gastroenterol Hepatol 2006; 4:6e10

3. Lal S, Teubner A, Shaffer JL. Review article: intestinal failure. Aliment Phar- macol Ther 2006;24:19e31.

4. Shils ME, Wright WL, Turnbull A, Brescia F. Long-term parenteral nutrition through an external arteriovenous shunt. N Engl J Med 1970 Aug 13;283(7): 341e4.

5. Solassol C, Joyeux H, Etco L, Pujol H, Romieu C. New techniques for long-term intravenous feeding: an artificial gut in 75 patients. Ann Surg 1974 Apr;179(4):519e22.

6. Reintam Blaser A, Malbrain ML, Starkopf J, Fruhwald S, Jakob SM, De Waele J, et al. Gastrointestinal function in intensive care patients: terminology, defi- nitions and management. Recommendations of the ESICM Workin Group on Abdominal Problems. Intensive Care Med 2012 Mar;38(3):384e94.

7. NHS National Commissioning Group for Highly Specialised Services. Strategic framework for intestinal failure and home parenteral nutrition services for adults in England. 2008. http://www.specialisedservices.nhs.uk/ library/28/Strategic_Framework_ for_Intestinal_ Failure_and_Home_Parenteral_ $\bar{N}$ utrition_Services_ for Adults in England 1.pdf.

8. Scöt NA, Leīnhardt $\bar{D} J, O$ 'Hanrahan T, Finnegan $S$, Shaffer JL, Irving MH. Spectrum of intestinal failure in a specialised unit. Lancet 1991;337:471e3.

9. Visschers RGJ, Olde Damink SWM, Winkens B, Soeters PB, van Gemert $W G$. Treatment strategies in 135 consecutive patients with enterocutaneous fis- tulas. World J Surg 2008; 32:445e53

10. Gardiner KR. Management of acute intestinal failure. Proc Nutr Soc 2011;70: 321e8.

11. Visschers RG, van Gemert WG, Winkens B, Soeters PB, Olde Damink SW. Guided treatment improves outcome of patients with enterocutaneous fis- tulas. World J Surg 2012;36: $2341 e 8$.

12. Forbes $A$. Challenges in treating intestinal failure and short bowel syndrome. ESPEN LLL Website, Module 12.2.

13. Visschers $R G$, Olde Damink $S W$, van Gemert $W G$, Soeters $P B$. Nutrition and gastrointestinal fistulas. ESPEN LLL Website, Module 12.3.

14. Gabe SM, Shaffer JL, Forbes A, Holst M, Irtun O, Klek S, et al. The management of patients with high output enterocutaneous gastrointestinal fistulae: a Eu-ropean Survey. Clin Nutr 2012;7(Suppl. 1):14e5.

15. Sobotka L. Basics in clinical nutrition. 4th ed. Galen; 2007.

16. Preiser JC, Schneider S. ESPEN disease e specific guideline framework. Clin Nutr 2011 Oct;30(5):549e52. http:// dx.doi.org/10.1016/j.clnu.2011.07.006. [17] Evenson AR, Fischer JE. Current management of enterocutaneous fistula. $J$ Gastrointest Surg 2006;10:455.

18. Gatt M, Reddy BS, MacFie J. Review article: bacterial translocation in the critically ill e evidence and methods of prevention. Aliment Pharmacol Ther 2007 Apr 1;25(7): $741 e 57$

19. De-Souza DA, Greene LJ. Intestinal permeability and systemic infections in critically ill patients: effect of glutamine. Crit Care Med 2005 May;33(5):1125e35.

20. Serejo LG, da Silva-Junior FP, Bastos JP, de Bruin GS, Mota RM, de Bruin PF. Risk factors for pulmonary complications after emergency abdominal surgery. Respir Med 2007;101(4):808e13.

21. Fruhwald $S$, Holzer $P$, Metzler $H$. Intestinal motility disturbances in intensive care patients pathogenesis and clinical impact. Intensive Care Med 2007 Jan;33(1):36e44 [Epub 2006 Nov 18].

22. Malbrain ML, Marik PE, Witters I, Cordemans C, Kirkpatrick 


\section{CLINICAL PRACTICE / EXPERIENCE}

$A W$, Roberts DJ, et al. Fluid overload, de-resuscitation, and outcomes in critically ill or injured patients: a systematic review with suggestions for clinical practice. Anaes- thesiol Intensive Ther 2014 NoveDec;46(5):361e80. http://dx.doi.org/ 10.5603/AIT.2014.0060.

23. Cederholm T, Bosaeus I, Barazzoni R, Bauer J, Van Gossum A, Klek $S$, et al. Diagnostic criteria for malnutrition $e$ an ESPEN Consensus Statement. Clin Nutr 2015;34(3): 335 e40.

24. Thibault R, Genton L, Pichard C. Body composition: why, when and for who? Clin Nutr 2012;31:435e47.

25. Kyle UG, Genton L, Karsegard L, Slosman DO, Pichard C. Single prediction equation for bioelectrical impedance analysis in adults aged 20 e94 years. Nutrition 2001;17: 248 e 53.

26. Selberg $O$, Selberg D. Norms and correlates of bioimpedance phase angle in healthy human subjects, hospitalized patients, and patients with liver cirrhosis. Eur J Appl Physiol 2002:86:509e16.

27. Barbosa-Silva MCG, Barros AJD, Post CLA, Waitzberg DL Heymsfield SB. Can bioelectrical impedance analysis identify malnutrition in preoperative nutri- tion assessment? Nutrition 2003;19:422e6.

28. Norman K, Smoliner C, Valentini L, Lochs H, Pirlich M. Is bioelectrical impedance vector analysis of value in the elderly with malnutrition and impaired functionality? Nutrition 2007:23:564e9.

29. Norman K, Stubler D, Baier P, et al. Effects of creatine supplementation on nutritional status, muscle function and quality of life in patients with colo- rectal cancer $e$ a double blind randomised controlled trial. Clin Nutr 2006;25: $596 e 605$.

30 SingerP, AnbarR,CohenJ, etal. The tightcaloriccontrol therapy (TICACOS): a prospective, randomised, controlled pilot study of nutritional support in critically ill patients. Intensive Care Med 2011;37:601e9.

31. Lawinski M, Singer P, Gradowski L, Bzokowska A, Majewska $K$. Predicted versus measured resting energy expenditure in patients requiring home parenteral nutrition. Nutrition 2015 Jun 1. http://dx.doi.org/10.1016/ j.nut.2015.05.002 [pii: S0899-9007(15)00217-8, Epub ahead of print].

32. Klek $S$, Chambrier $C$, Singer $P$, Rubin $M$, Bowling $T$, Staun $M$, et al. Four week parenteral nutrition using a third generation lipid emulsion (SMOFlipid) e a double-blind, randomised, multicentre study in adults. Clin Nutr 2013 Apr:32(2):224e31.

33. Singer P, Berger MM, Van den Berghe $G$, Biolo $G$, Calder $P$, Forbes $A$, et al., ESPEN. ESPEN guidelines on parenteral nutrition: intensive care. Clin Nutr 2009:28:387e400.

34. Van Citters $G W$, Lin HC. Ileal brake: neuropeptidergic control of intestinal transit. Curr Gastroenterol Rep 2006 Oct:8(5):367e 73 .

35. Altomare DF, Serio G, Pannarale OC, Lupo L, Palasciano $N$, Memeo $V$, et al. Prediction of mortality by logistic regression analysis in patients with post-operative enterocutaneous fistulae. Br J Surg 1990 Apr;77(4):450e3.

36. Rinsema $W$, Gouma DJ, von Meyenfeldt MF, Soeters PB. Reinfusion of secre-tions from high-output proximal stomas or fistulas. Surg Gynecol Obstet 1988 Nov;167(5):372e6.

37. Teubner A, Morrison K, Ravishankar HR, Anderson ID, Scott NA, Carlson GL. Fistuloclysis can successfully replace parenteral feeding in the nutritional support of patients with enterocutaneous fistula. Br J Surg 2004 May;91(5). 625 e 31

38. Pflug Adriano M, Utiyama Edivaldo $M$, Fontes Belchor, Faro Mario, Rasslan Samir. Continuous reinfusion of succus entericus associated with fistuloclysis in the management of a complex jejunal fistula on the abdominal wall. Int $J$ Surg Case Rep 2013;4(8):716e8. http://dx.doi.org/ $10.1016 /$ j.ijscr.2013.04.041

39.Picot D, Garin L, Layec S, Trivin F. Insuffisance intestinale des enterostomies temporaires: traitement par reinstillation du chyme. 138 patients. J Chirurgie Viscerale 2010;17: $27 e 8$.

40. Picot D, Garin L, Trivin F Darmaun D, Thibault R. Plasma citrulline is a marker of absorptive small bowel length in patients with transient enterostomy and acute intestinal failure. Clin Nutr 2010:29:235e42.

41. Bjornsdottir R, Oskarsdottir ES, Thordardottir FR, Ramel
PAIN, ANAESTHESIA \& INTENSEIVE CARE IN2 2017

A, Thorsdottir, Gunnarsdottir I. Validation of a plate diagram sheet for estimation of energy and protein intake in hospitalized patients. Clin Nutr 2013;32(5):746e51.

42. Gariballa SE, Forster SJ. Dietary intake of older patients in hospital and at home: the validity of patient kept food diaries. Nutr Health Aging 2008;12(2): 102e6.

43. Frederick PL, Sizer J, Osborne MP. Relation of massive bowel resection to gastric secretion. $N$ Engl J Med $1965 ; 10: 509$ e 14 .

44. Reul GJ, Ellison EH. Effect of seventy-five per cent distal small bowel resection on gastric secretion. Am J Surg 1966;111:772e6.

45. Sharma M, Rao M, Jacob S, Jacob CK. Validation of 24hour dietary recall: a study in hemodialysis patients. J Ren Nutr 1998;8(4):199e202.

46. Thibault R, Goujon $N$, Le Gallic E, Clairand $R$, Sebille $V$ Vibert $J$, et al. Use of 10-point analogue scales to estimate dietary intake: a prospective study in pa-tients nutritionally at-risk. Clin Nutr 2009:28:134e40.

47. Van Op den Bosch J, Adriaensen D, Van Nassauw L, Timmermans JP. The role(s) of somatostatin, structurally related peptides and somatostatin re-ceptors in the gastrointestinal tract: a review. Regul Pept 2009;156:1e8.

48. Allen PJ, Go€nen M, Brennan MF, Bucknor AA, Robinson LM, Pappas MM, et al. Pasireotide for postoperative pancreatic fistula. N Engl J Med 2014;370: $2014 e 22$.

49 Ramos-De la Medina A, Sarr MG. Somatostatin analogues in the prevention of pancreas-related complications after pancreatic resection. J Hepatobiliary Pancreat Surg 2006; 13:190e3

50. Sarr $M G$. The potent somatostatin analogue vapreotide does not decrease pancreas-specific complications after elective pancreatectomy: a prospective, multicenter, doubleblinded, randomized, placebo-controlled trial. J Am Coll Surg 2003:196:556e64.

51. Thibault R, Graf S, Clerc A, Delieuvin N, Heidegger CP, Pichard $C$. Diarrhoea in the intensive care unit: respective contribution of feeding and antibiotics. Crit Care 2013;17:R153.

52. Reintam Blaser A, Deane AM, Fruhwald S. Diarrhoea in the critically ill. Curr Opin Crit Care 2015 Apr;21(2):142e53. http://dx.doi.org/10.1097/ MCC.00 00000000000188

53. Rahbour $G$, Siddiqui MR, Ullah MR, Gabe SM, Warusavitarne J, Vaizey CJ. A meta-analysis of outcomes following use of somatostatin and its analogues for the management of enterocutaneous fistulas. Ann Surg 2012 Dec;256(6): $946 e 54$

54. Liddle $C$. Nil by mouth: best practice patient education. Nurs Times 2014 Jun 25eJul 1;110(26):12e4. PMID: 25087264.

55. Berry AM. Consensus based clinical guideline for oral hygiene in the critically ill. Intensive Crit Care Nurs 2011 Aug;27(4):180e5. http://dx.doi.org/10.1016/ j.iccn.2011. 04.005 .

56. Pronovost $P$, Needham D, Berenholtz $S$, Sinopoli D, Chu $H$, Cosgrove $S$, et al. An intervention to decrease catheterrelated bloodstream infections in the ICU. N Engl J Med 2006 Dec 28;355(26):2725e32.

57. Lai NM, Chaiyakunapruk N, Lai NA, O'Riordan E, Pau $W S$, Saint $S$. Catheter impregnation, coating or bonding for reducing central venous catheter-related infections in adults. Cochrane Database Syst Rev 2013 Jun 6:6: CD007878. $\quad$ http://dx.doi.org/10.1002/14651858. CD007878 pub2.

58. Hammarskjo€ld $F$, Berg $S$, Hanberger $H$, Taxbro $K$, Malmvall BE. Sustained low incidence of central venous catheter-related infections over six years in a Swedish hospital with an active central venous catheter team. Am J Infect Control 2014;42(2):122e8.

59. Vather R, Bissett I. Management of prolonged post-operative ileus: evidence-based recommendations. ANZ J Surg 2013 May;83(5):319e24. http:// dx.doi.org/10.1111/ans.12102 [Epub 2013 Feb 19. Review. PMID: 23418987]. [60] Drolet $A$, et al. Move to improve: the feasibility of using an early mobility protocol to increase ambulation in the intensive and intermediate care settings. Phys Ther February 2013;93(2):197e207. PMID: 22976447. 
61. Lunardi AC, Mirands CS, Silva KM, Cecconello I, Carvalho CR. Weakness of expiratory muscles and pulmonary complications in malnourished patients undergoing upper abdominal surgery. Respirology 2012;17(1):108e13.

62. McClave S, De Meo MT, De Legge MH, et al. North American summit on aspiration in the critically ill patient: consensus statement. J Parenter Enteral Nutr 2002;26:80e5.

63. Hughes MJ, Ventham NT, McNally S, Harrison E, Wigmore $S$. Analgesia after open abdominal surgery in the setting of enhanced recovery surgery: a sys-tematic review and meta-analysis. JAMA Surg 2014 Dec;149(12):1224e30.http://dx.doi.org/10.1001/ jamasurg. 2014.210 .

64. Werawatganon T, Charuluxanun S. Patient controlled intravenous opioid analgesia versus continuous epidural analgesia for pain after intra-abdominal surgery. Cochrane Database Syst Rev 2005 Jan $25 ; 1: C D 004088$.

65. Carlson GL. Surgical management of intestinal failure. Proc Nutr Soc 2003;62: 711e8.

66. Carlson GL, Gardiner $K$, McKee R, MacFie J, Vaizey $C$. The surgical management of patients with intestinal failure. Issues in professional practice. Association of Surgeons of Great Britain and Ireland; 2010.

67. Koperna T, Schulz F. Relaparotomy in peritonitis: prognosis and treatment of patients with persisting intraabdominal infection. World J Surg 2000;24: 32e7.
68. Alderson P, Bunn F, Lefebvre C, Li WP, Li L, Roberts I, et al. Human albumin solution for resuscitation and volume expansion in critically ill patients. Cochrane Database Syst Rev 2004:4:CD001208.

69 Gabe SM, Culkin A. Abnormal liver function tests in the parenteral nutrition fed patient. Frontline Gastroenterol 2010;1:98e104. http://dx.doi.org/ 10.1136/fg.2009. 000521.

70. Lindor $K D$, Fleming $C R$, Abrams $A$, et al. Liver function values in adults receiving total parenteral nutrition. $J$ Am Med Assoc 1979;241:2398e400.

71. Staun M, Pironi L, Bozzetti F, Baxter J, Forbes A, Joly F, et al. ESPEN guidelines on parenteral nutrition: home parenteral nutrition (HPN) in adult patients. Clin Nutr 2009;28:467e 79.

72. Quigley EM, Marsh MN, Shaffer JL, et al. Hepatobiliary complications of total parenteral nutrition. Gastroenterology 1993;104:286e301.

73. Pironi L, Arends J, Bozzetti F, Cuerda C, Gillanders L, Jeppesen PB, et al., Home Artificial Nutrition \& Chronic Intestinal Failure Special Interest Group of ESPEN. ESPEN guidelines on chronic intestinal failure in adults. Clin Nutr 2016 Apr;35(2):247e307. http://dx.doi.org/ $10.1016 / j . c \operatorname{lnu} .2016 .01 .020$

74. Dreesen M, Foulon V, Spriet I, Goossens GA, Hiele M, De Pourcq L, et al. Epidemiology of catheter-related infections in adult patients receiving home parenteral nutrition: a systematic review. Clin Nutr 2013 Feb;32(1):16e26. http:/ /dx.doi.org/10.1016/j.clnu.2012.08.004. 